Snežana Živković ${ }^{1}$

P. 37-47

Milan Veljković ${ }^{2}$

Faculty of Occupational Safety, Niš, Serbia

SCIENTIFIC REVIEW ARTICLE

DOI: $10.5937 /$ ESD2002037Z

Received: May, 06. 2020.

Accepted: July, 11. 2020.

\title{
THE CONCEPT AND OBJECTIVES OF ENVIRONMENTAL MANAGEMENT
}

\begin{abstract}
Environment protection has become a very common subject of discussion all over the world due to the destructive influence of man's economic activities on the environment in the name of sustainable global economy. The purpose of this paper is to address the issue of environmental management as a part of the overall management system. The aim of the paper is to emphasize the significance of environmental management and its concern with the management for environment encompassing a business. Sound environmental management can only be equated with good management and should have sufficient measures for minimizing the environmental damage.
\end{abstract}

Key words: environmental management, standards, management systems, environmental management instruments

JEL classification: R11

\section{КОНЦЕПТ И ЦИЉЕВИ УПРАВЉАҢА ЗАШТИТОМ ЖИВОТНЕ СРЕДИНЕ}

\begin{abstract}
Апстракт
Заштита животне средине је постала веома уобичајена тема дискусије у иелом свету због деструктивног утииаја човекових економских активности на животну средину у ициу одрживе глобалне економије. Сврха овог рада јесу проблеми управљања животном средином као дела укупног система менаимента. Циљ рада је нагласити значај управљања животном средином и юеговим интересом за управљањем животном средином које обухвата пословне активности. Разумно управљање животном средином може се изједначити са добрим менаиментом и требало би садржати адекватне мере за минимизирање итете по животну средину.
\end{abstract}

Кључне речи: управљање заштитом животне средине, стандарди, системи управљаға, инструменти за управљағе животном средином

\footnotetext{
${ }^{1}$ snezana.zivkovic@znrfak.ni.ac.rs, ORCID ID 0000-0002-7931-9334

${ }^{2}$ milan.veljkovic@znrfak.ni.ac.rs, ORCID ID 0000-0002-3318-6732
} 


\section{Introduction}

The concept of environmental management is not easy to define. Environmental management is a young scientific discipline created in the field of ecology at the end of the last century with the task of reducing, to the minimum dimensions, the impact of technical and technological development on the biosphere and the survival of living beings (Živković, 2016).

It may be related to goals or visions, attempts to direct a process, the application of a series of tools, philosophical practices that aims to establish new perspectives on the environment and human society, and so on. The managers of environmental protection can be counted among different groups of people, which include scientists, policy makers, NGO workers, employees in companies, public officials and a wide range of people or groups of people who make decisions that affect the way we use natural resources (E.g. fishermen, farmers and herders). Environmental management extends to all human beings to some extent, since ultimately all human activities have some environmental impact. However, some people are more directly involved in the use of resources, while certain interest groups are particularly concerned about resource development and pollution. Therefore, environmental management requires a multidisciplinary perspective.

A team of HR professionals dealing with sustainability issues represents employees as an interest group that plays a key role in forming 'green teams' and encouraging employee engagement in environmental and other issues. The HR team also accomplishes goals that are their responsibility, such as employee fluctuations, safety at work, and employee satisfaction. Green Human Resources utilizes the employee's ability to respond to environmental sustainability promotion requirements through the results of their work and improve employee awareness and commitment to sustainability issues (Elesawi, 2018).

In order to enable a shift towards the desired environmental situation in the future, planning methods and models must be used to help accurately guide sustainable development policy. Therefore, it is necessary to develop methods of environmental management at the level of theory, as well as at the level of regulations, standards and guidelines. A precondition for any effective environmental management is a firm control over the execution policy in order to achieve effective democratic governance. This requires responsible elected representatives at all levels, and at the central level, effective committees that can assist in the adoption of sustainable environmental policy, review proposed laws and regulations, monitor the effectiveness of the implementation of adopted laws, conduct investigative hearings and play a key role in regional networks (Entesar, 2018).

It includes a number of scales, from local to global. It also covers a wide variety of goals, including the will to control the direction and pace of development, optimize resource use, minimize environmental degradation, and avoid environmental disaster. Individuals and groups that have opinions and even directly opposing views can carry out environmental management. For example, when environmental managers employed by large multinational companies conflict with environmental managers representing voluntary organizations.

However, in general, environmental management is concerned with understanding the structure and function of the terrestrial system, as well as how humans relate to their environment. Consequently, environmental management is concerned with identifying, observing and tracking environmental change, predicting potential changes and making 
an attempt to optimize human benefits and diminish environmental destruction which are caused by the behavior and activities of men. However, it is characteristic that environmental management is about decision-making - and it is especially concerned with the decisionmaking process regarding the use of natural resources, pollution of habitats and ecosystem modification (Martín \&de Castro, Amores \& Salvadó \& Navas \& López, 2016).

Eco-management involves planning, organizing, personnel policy, leadership and process control. Capability development in environmental management is conditioned by education and training.

\section{Environmental management - good business practice}

Environmental management is part of good business practices in all organizations that have a clear strategy and target based on constant improvement of its processes. For organizations involved in sustainable urban development planning, it is a challenge and a way to prove and commit to new approaches, new philosophies, a new way of thinking, a critical and scientific approach, a willingness and capacity to change, to abandon half-lives and undertake business and other ventures with better efficiency and with a general affirmation of effective practice (Grujić \& Živanović, 2012).

The principles and elements of environmental management strategies include the following:

- Environmental policy;

- Planning;

- Implementation and implementation verification and corrective action;

- Review and improvement;

- Continuous improvement (Đukanović, 1996).

Essentially, environmental management is a political issue because decisions regarding resources, pollution and the environment are not made according to ecological goals but according to the possibilities dictated by the authorities and interest groups. Moreover, in the sense that humans manipulate and control the components and processes of terrestrial systems, it is usually naive to regard environmental management as simple "environmental management". Instead, the more accurate is to suggest that people may be able to advance in the management of human influence on a particular system. Finally, environmental management pays more attention and it more conceted to the management of human activities and their impacts, rather than natural impacts.

Nevertheless, some types of activities are common to environmental managers. Environmental managers try to deliberately manage the development process to take advantage of opportunities; they seek to ensure that critical environmental boundaries are not exceeded; work to reduce and mitigate environmental problems; and they are concerned about increasing the adaptability and resilience of human societies in the context of environmental change, changeability, unpredictability and danger (Batle, Orfila-Sintes \& Moon, 2018).

From this point of view, environmental management can be defined as a system that anticipates and avoids or solves environmental and resource problems. On the other point of view, environmental management can be defined as a process that refers to the interaction between man and the environment that aims to identify: 
- What are the environmentally desirable outcomes?

- What are the physical, economic, social, cultural, political and technological constraints to achieving these results?

- What are the best options for achieving these results?

Indeed, in many parts of the world (and perhaps around the world) environmental management is closely linked to issues of justice and even survival. Further definition may suggest that environmental management is concerned with meeting and improving human security and requirements in a sustainable manner with minimal damage to natural habitats and ecosystems. Therefore, the concept of sustainable development, as one of the problematic and very important concepts, is closely related to the concept of environmental management.

The implementation of eco-management in ecology and sustainable development imposes certain changes in thinking and business. Environmental management is about environmental planning and its focus is on implementation, monitoring, control as well as practical issues that need to be addressed in terms of environmental conservation, for example, modifying habits that are detrimental to human nature, and is much more than theoretical planning (Milutinović, 2012).

The objectives of environmental management include:

- Prevention and resolution of environmental problems;

- Establishing borders;

- Establishment and maintenance of institutions that effectively support environmental research, monitoring and management;

- Hazard warning and identification of ways to overcome them;

- Maintain and if possible improve existing resources;

- Where improvement in "quality of life" is possible;

- Identifying useful new technologies or policies (Živković, 2016).

Too much environmental awareness and quality of life have developed over the last three decades. The vocabulary of the environment is regularly updated with new terminologies such as clean technology, environmental auditing, environmental products, environmental impact assessment, conservation of life resources, etc.

Now the time has come when our policy makers and society should aim to protect, preserve and regulate development in a manner that will not create harmful effects on ecosystems and human needs can also be met. All over the world, especially in developing countries, these are the urgent need to manage the entire environment. In the first place, environmental management has three things to do:

- Identify goals;

- Determine if they can be fulfilled;

- Develop and implement the tools that can be done.

Environmental management is therefore an approach that integrates ecology, policy making, planning and social development (Famiyeh et al., 2018).

Some of the goals have been formally set. Thus, for example, the first principle of the Rio Declaration on Environment and Development explicitly formulates that human beings have a central place in the concern for sustainable development. They have the right to a healthy and productive life in harmony with nature. Agenda 21, as the broadest global document adopted at the World Summit on the Environment and Sustainable Development in 
Rio in 1992 in Chapter 30, which focuses on strengthening the role of business and industry, contains two separate programs:

- Improving cleaner production;

- Improving the responsibility of entrepreneurship.

The objectives of environmental management can also be viewed through the objectives of the environmental management system. The objectives of eco-management (according to the EMAS Rule 2001) can also be viewed as general. The overall objective is to evaluate and improve the environmental performance of an organization and to provide relevant information to the public and other interested parties (Živković, 2016).

\section{Environmental management systems}

The system can be interpreted as a number of interconnected elements that work together to achieve a clearly defined objective. Therefore, it can be said that the system of environmental management consists of a set of interconnected elements that work together to achieve the goal of an efficient environmental management. So what are the elements that make up an environmental management system? Many larger companies have had environmental management systems in place for many years. As each company has designed its system to meet its specific needs, these systems vary greatly, i.e. they contain a different combination of elements. However, recently the International Organization for Standardization (ISO) formulated a common model of an environmental management system with the elements that an environmental management system should contain. The model is designed to be applicable to organizations of all types and sizes worldwide and is considered an established standard.

The international standard ISO 14001 is a standard for management that aims to support a comprehensive environmental protection. The standard is written in a manner that is applicable to all types and sizes of organizations, and can be adapted to different geographical, cultural and social conditions.

This International Standard specifies the requirements relating to the system of environmental management, to enable it to develop and implement a policy and objectives of environmental protection taking into account all legal and other regulations with which organizations agreed on, as well as information on significant impacts to the environment (Heras \& Saizarbitoria, Arana \& Boiral, 2016).

Environmental Management Systems ISO 14001:2004 is a management tool that enables an organization of any size to:

- identify and control the environmental impact of its activities, products and services;

- improves the attitude towards the environment;

- implement a systematic approach that will achieve environmental goals and provide evidence that it has achieved its objectives.

The ISO 14001 elements are organized around 5 steps:

Step 1 - Environmental Policy

The company makes a policy that outlines its intentions with respect to the environment. 
The policy must include obligations to:

- Continues to make progress;

- Prevents pollution;

- Complies with relevant environmental legislation and other legal requirements.

ISO 14001 defines the "continuous improvement" as the process of improving the system of environmental management in order to achieve performance improvement in the environment in accordance with the environmental policy of the organization. The environmental policies of companies shall include the obligation on continuous improvement, prevention of pollution and in accordance with the relevant legislation in the field of environment. In addition, the policy must provide a framework for setting goals that must be communicated to all employees and must be publicly available.

\section{Step 2 - Planning}

The company then must themselves set targets relating to their political commitment and devise a plan to meet these goals. The first thing he has to do is identify what the standard calls "environmental aspects". They are defined as "elements of activities, products or services of the organization that can interact with the environment." Once you determine its aspects of environmental protection, the company must establish which of them were "significant", ie. which of them have a significant environmental impact. In order to identify its significant environmental aspects, a company must carry out an "environmental review". It should be emphasized that environmental audit is the foundation upon which the rest of the management system is built and should be carried out as thoroughly as possible.

\section{Step 3 - Implementation and operation}

After reviewing its plan, the company must then establish the various elements necessary for its successful implementation and operation. The following elements necessary for the successful implementation and functioning of an environmental management program are:

- Structure and responsibility;

- Training, awareness and competence;

- Communication;

- Documentation of the environmental protection system;

- Document control;

- Operational control;

- Emergency preparedness and response.

\section{Step 4 - Check and corrective action}

After application of the plan, the company must check whether it was successful in meeting its objectives. If not met, they must take corrective measures. The entire management system must be periodically inspected to see if it meets the requirements of the standard. The company must establish and maintain documented procedures for regular monitoring and measurement, those areas covered by the objectives to see if they met. The company must also establish and maintain a documented procedure for periodically assessing compliance with relevant environmental legislation and regulations.

Step 5 - Management Report

Management must periodically review the system to ensure its continued efficiency and convenience. Changes are made to the system as needed. The review must address the 
possible need for changes to the policy, objectives and other elements of the environmental management system due to the following items:

- Audit results;

- Changes in circumstances and

- The company's commitment to continuous improvement.

The main reasons that lead to the expressed need for the introduction of an environmental protection system ISO 14001: 2004 are:

- Continuous pollution;

- Fear of complete depletion of natural resources;

- Lack of organized and systematic monitoring of pollution consequences;

- Increased public interest in environmental protection;

- Legal solutions;

- Special working conditions in vulnerable areas.

The advantages of implementing ISO 14001 environmental protection system:

- Reduction of negative effects on the environment;

- Reducing the risk of environmental disasters;

- Increasing the ability to respond quickly and effectively;

- Improved reputation and trust in the community;

- Competitive advantage;

- Legal certainty for compliance with environmental laws;

- Easier obtaining of authority and permits from local and state authorities;

- Improving your reputation and that of your client;

- Better use of energy and protection of water, careful selection of raw materials and controlled waste recycling, contributes to lower costs and increases your competitiveness;

- Reduces your financial burden due to reactive management strategies such as repairs, cleanups, violation of laws;

- Improving the quality of jobs and employee morale;

- New employment opportunities are opening up in markets where organic production is important;

- Environmentally conscious customers will deal with companies like yours as it emphasizes its commitment to the environment (ISO, 1996).

\section{Environmental standards - ISO 14000}

The areas in which the ISO 14000 series are classified include 34 standards for systems, processes and products.

1. An environmental management system where ISO 14001: 2015 applies;

2. Environmental Research and Verification (ISO 14020) - includes site evaluation, verification guide;

3. Environmental labeling - consists of environmental-related type I, II and III declarations and labels (ISO 14020 series);

4. Environmental performance evaluation - evaluation of technologies, communications and qualitative information (ISO 14030 series); 
5. Life cycle assessment - guidelines and requirements, principles and framework, eco-efficiency assessment of product systems (ISO 14040 series);

6. Greenhouse gas management $(\mathrm{GHG})$ - requirements for verification bodies, team competence requirements, GHG reporting (ISO 14060 series);

7. General locations, which include definitions, terms, and cost accounting for material flows (ISO 14050) (Radovanović, 2018).

\section{EMAS (Eco Management and Audit Scheme)}

European Commission developed EMAS (management tool) for companies and organizations to evaluate, report and improve environmental performance. EMAS is open to any type of organization that wants to improve its environmental performance. It covers all sectors of the economy and services and is applicable worldwide.

The EMAS system has the principle of voluntariness and accessibility to all economic sectors. The key features of EMAS are transparency, accuracy and efficiency. EMAS is a system harmonized at EU level (European Commission, 2017).

The EMAS system provides:

1. Greater credibility, transparency and reputation;

2. Enhanced management of environmental risks and opportunities;

3. Better environmental and financial results;

4. Greater employee motivation.

\section{Environmental management instruments}

Environmental management methods and instruments are systematic means of obtaining environmental information and helping to make decisions about the environmental impact of ongoing or planned activities to protect and improve the environment, or to achieve the goals of sustainable development. These funds can be used by all social actors (whether from the private or public sector), in sims and at all levels, from local, through regional, national to international (Entesar, 2018).

There are a number of management tools (mechanisms, resources, methodologies) that are currently in use or can be used to achieve specific environmental goals. The most interesting classification of environmental management instruments is according to the criteria of the entities applying them, and it is possible to distinguish: instruments in the creation, implementation or implementation of which international organizations have a leading role; instruments for the implementation of which are the responsibility of the States; instruments pertaining to business organizations and instruments created for the most part to enable public participation in decision-making processes. The complexity of individual management instruments should be taken into account.

Environmental management instruments are:

- Planning instruments;

- Economic instruments;

- Legal instruments;

- $\quad$ Environmental Impact Assessment; 
- Monitoring and evaluation instruments and management instruments that are largely inherent in business organizations: the concept of clean production; integrated production policy;

- $\quad$ Life cycle assessment;

- $\quad$ Risk assessment and risk management;

- Environmental verification;

- Eco-labeling;

- Environmental performance evaluation;

- Environmental accounting;

- Green Procurement;

- Voluntary agreements;

- Environmental management systems;

- Instruments derived from the concept of integrated pollution prevention and prevention;

- Procedures related to public participation and the concept of sustainable production.

In practice, a greater number of eco-management and / or environmental management tools are being implemented. Some of the instruments are used as a legal obligation, some are standardized according to national or international standards and their implementation is voluntary, while others are in the development and refinement phase.

According to the OECD, the following economic instruments exist:

1. Fees and taxes on pollution emissions;

2. User fees and taxes;

3. Penalties;

4. Product fees;

5. Performance guarantees and,

6. Damages (Popov, 2011).

Strategic environmental assessment can take many forms:

1. Sectoral (transport, energy, water management development strategies);

2. Spatial (assessment of spatial plans at national, regional and local level);

3. Indirect (environmental assessment of scientific programs, plans for privatization of public companies, etc.).

The scope of strategic environmental assessment involves testing the quality of: air, water, land, biodiversity, as well as waste recycling. In addition, it may include multisource impact assessment (cumulative impact assessment) and social impact assessment (Mihajlović, Stojanović \& Ilić, 2011).

\section{Conclusion}

The goal of environmental management is improved quality of human life. The main concern of the environmental management is to meet and improve human needs and demands provision on a sustainable basis while having a minimal damage to natural habitats and ecosystems. 
An environmental management system refers to the management of an organization's environmental programs in a planned, comprehensive, systematic and documented manner. It includes the organizational structure, and the planning and resources for developing, implementing and maintaining policy for environmental protection. Also, it serves as a tool for environmental performance improvement and provides a systematic way to manage the affairs of the particular business entity environmental affairs. The environmental management standard seeks to reduce the impact on the environment as measured by some objective criterion. The most widely used standard for environmental risk management is ISO 14001 standard.

Greater political and social demands on companies to mitigate their environmental impact were driven by increasing awareness of environmental problems caused by economic activity. This led to emergence of an organization's ability to manage corporate environmental performance as a strategic issue for companies. By proper implementation of environmental management techniques and tools, the company can manage its impact on the environment - reduce energy consumption and emissions, increase water usage efficiency and achieve better management of waste. The advantages of using an environmental management system include ensuring a holistic approach to environmental impacts while gaining economic benefits such as lower environmentally related costs and fees and direct savings through environmental source reduction.

\section{Acknowledgement}

This paper is the result of research funded by the Ministry of Education, Science and Technological Development of the Republic of Serbia.

\section{References}

Batle, J., Orfila-Sintes, F., \& Moon, C. J. (2018). Environmental management best practices: Towards social innovation. International Journal of Hospitality Management, 69, $14-20$.

Đukanović, M. (1996). Životna sredina i održivi razvoj. Elit, Beograd.

Elesawi, A. (2018). Uloga energetske efikasnosti u sistemu održivog razvoja na primeru održive izgradnje u Libiji, Doktorska disertacija, Univerzitet Union Nikola Tesla, Fakultet za graditeljski menadžment, Beograd.

Entesar, S. (2018). Značaj ekoloških standarda i ekološkog upravljanja za održivi razvoj Libije, Master rad, Univerzitet Singidunum, Fakultet za primenjenu ekologiju Futura, Beograd.

European Commision (2017). What is EMAS? Dostupano na: https://ec.europa.eu/ environment/emas/index_en.htm

Famiyeh, S., Adaku, E., Amoako-Gyampah, K., Asante-Darko, D., \& Amoatey, C. T. (2018). Environmental management practices, operational competitiveness and environmental performance. Journal of Manufacturing Technology Management, 29(3), 588-607. 
Grujić, K., Živanović, N. (2012). Ekološki menadžment trendovi razvoja u ambijentu, Međunarodna naučna konferencija "Menadžment 2012", Zbornik radova, Mladenovac.

Harmath, P. (2007). Strukturiranje organizacija u funkciji ekološkog menadžmenta. Anali Ekonomskog fakulteta u Subotici, (18), 199-209.

Heras-Saizarbitoria, I., Arana, G., \& Boiral, O. (2016). Outcomes of environmental management systems: The role of motivations and firms' characteristics. Business Strategy and the Environment, 25(8), 545-559.

Institut za standardizaciju Srbije (2015). Sistemi menadžmenta. ISS, Beograd. Dostupno na https://www.iss.rs/button_104.html

Martín de Castro, G., Amores Salvadó, J., \& Navas López, J. E. (2016). Environmental management systems and firm performance: improving firm environmental policy through stakeholder engagement. Corporate social responsibility and Environmental Management, 23(4), 243-256.

Mihajlović, D., Stojanović, D., Ilić, B. (2011). Ekološki menadžment u funkciji društveno ekonomskog održivog razvoja. Fakultet organizacionih nauka, Beograd.

Milutinović, S. (2012). Politike održivog razvoja. Fakultet zaštite na radu u Nišu, Niš.

Popov, Đ. (2011). Ekonomska analiza prava životne sredine i održivi razvoj, Zbornik radova Osnove prava životne sredine, Pravni fakultet Novi Sad, Novi Sad.

Radovanović, B. (2018). Finansiranje zaštite životne sredine u Republici Srbiji, Doktorska disertacija, Alfa BK Univerzitet, Fakultet za finansije, bankarstvo i reviziju, Beograd.

Živković, S. (2016). Upravljanje zaštitom životne sredine, Materijal u pripremi, Fakultet zaštite na radu u Nišu, Niš. 